\title{
変位モード指定の構造形態解析法 ANALYTICAL METHOD OF STRUCTURAL SHAPE UNDER THE PRESCRIBED DISPLACEMENT MODE
}

\author{
半谷裕彦*, 原田和明** \\ Yasuhiko HANGAI and Kazuaki HARADA
}

\begin{abstract}
An analytical method of structural shape, which belongs to the inverse problem in the field of structural analysis, is presented under the prescribed displacement mode. First, the loaddisplacement relation whose coefficient matrix is a function of an unknown position vector representing the structural shape, and the subsidiary condition for the prescribed displacement mode are formulated. Then, these two equations are analytically analyzed by using the Bott - Duffin in verse matrix. The obtained nonlinear equation which is a function of a position vector is numerically analyzed by Newton-Raphson method and by steepest descent method. Numerical examples show the varidity of the proposed method.

Keywords : shape analysis, inverse problem, Bott.Duffin inverse, generalized inverse, NewtonRaphson method, steepest descent method

形態解析，逆問題，Bott · Duffin 逆行列，一般逆行列，Newton-Raphson 法，最大傾 斜法
\end{abstract}

\section{1. 研究目的}

構造解析の分野における逆問題のひとつに, 形態解析 がある。 $\boldsymbol{x}$ を構造物の形態を表する位置ベクトルとす るとき, 応力解析では形態 $\boldsymbol{x}$, 外力 $\boldsymbol{f}$, 境界 $\boldsymbol{C}$ を指定 して, 変位 $\boldsymbol{d}$ や応力 $\sigma$ を解析する $($ 図一 1 )。一方, 形 態解析では，変位や応力（あるいはその一部）等を指定 して構造形態 $x$ を解析する。応力解析の方向を順方向 とすると形態解析の方向は逆方向となっている。応力解 析においては，線形の基礎方程式を採用する場合，解の 存在や唯一性は保証されている。しかし，形態解析では 特別な場合を除き，非線形基礎方程式となり，解の存在 や唯一性は保証されない。そのため, 基礎方程式の定式化 や解析法の開発に工夫が要求され，未解決な問題が多い。
形態解析法に関する既往の研究としては, 梅谷の成言 変形法" ${ }^{1}$, 尾田によるパターン変換法 ${ }^{21}$, 中桐の構造シ ンセシスによる方法 ${ }^{31}$, 瀬口らによる逆変分原理に基ゔ く方法 ${ }^{4)}$, 畔上の成長の構成則を取り入れた方法 ${ }^{51}$, , 半 谷らの一般逆行列による方法 ${ }^{6}$, 中村らの形態創成法に

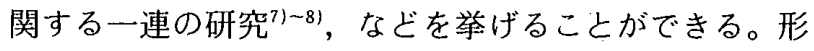
態解析を扱っている図書，レヴュ一論文として・9)〜15) をあげておく。

形態解析を行う場合には，目標とする量；あるいは形 態が必要である。既往の研究の多くは，最小重量や最大 剛性，あるいは，一様応力や一様ひずみエネルギ一密度， 等を目標としている。本論文では「指定した荷重下にお いて, 構造，あるいは，構造の一部が変形前，後におい
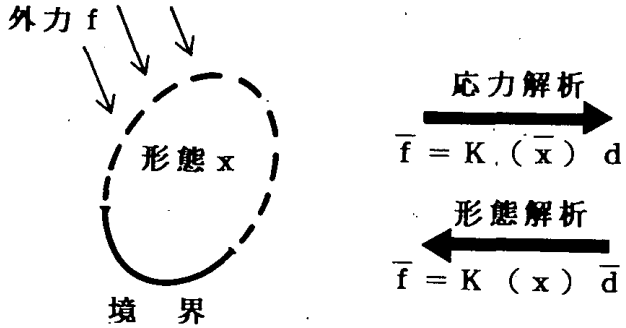

図一1 応力解析と形態解析（一は指定する量を示す）
て指定した形状と同一となるように構造形態 を決定すること」を目標とする。著者らは変 位モード指定下において立体トラス構造の形 態解析法をホモロガス変形の概念とともに提 案した ${ }^{6 !}$ 。その際，一般逆行列を利用した解 の存在条件を基礎とし,解析法を定式化した。 一方，制約条件付きの連立方程式の解法とし ての Bott・Duffin 逆行列を利用し，変位制
* 東京大学生産技術研究所 教授.工博

** 東京電力 (株) 技術研究所構造研究室 主任・工修
Prof., Institute of Industrial Science, Univ. of Tokyo, Dr. Eng. Research Eng., Engineering Reaearch Center, Tokyo Electric Power Company, M. Eng. 
限を持つ構造物の解析法を提案した ${ }^{16)}$ 。本論文では Bott・Duffin 逆行列を利用した変位モード指定の形態 解析法を述べる。

\section{2. 基礎方程式}

有限要素法, 差分法, ガラーキン法, 等により離散型 の荷重・変位関係を求め, 境界処理を行うと次式に帰着 できる。

$$
f=K(x) d
$$

ここに, $\boldsymbol{f}:$ 外力ベクトル, $\boldsymbol{K}(\boldsymbol{x})$ : 剛性マトリクス, $d$

: 変位ベクトル, $\boldsymbol{x}$ : 構造形態を表す座標パラメータ, である。ここで， $x$ を 4 個のグループに分類する（図 $-2)$ 。

$x_{h}$ : 変位モード指定を受ける座標パラメータ

(自由度 $h$ )

$x_{f}:$ 形態変化する独立な座標パラメータ

(自由度 $f$, 末知量)

$x_{g}:$ 形態変化する従属な座標パラメータ

(自由度 $g, x_{g}=g\left(x_{f}\right)$ )

$x_{c}$ : 形態変化しない固定された座標パラメータ

(自由度 $c$ )

全自由度数は $n=h+f+g+c$ で, $K$ は $n \times n$ マトリ クスとなっている。

変形後の形態は, 変形前の形態に変位を加えることで 表すことができるので，指定する形態を変位モードを用 いて次式で与える。

$$
\boldsymbol{A d}=\mathbf{0} \text {. }
$$

ここに，A は $m \times n$ マトリクスで， $m$ は制約条件数で ある。ただし， $m<n$ とする。式（2）において，制約 条件をすべて独立であるとすると次式が成立する。

$$
\operatorname{rank}(\boldsymbol{A})=m
$$

$A$ の行数とランクが一致しており, 次式が成立する ${ }^{10)}$ 。

$$
A^{+}=A^{T}\left(A A^{T}\right)^{-1}
$$

ここに, $\boldsymbol{A}^{+}$は $\boldsymbol{A}$ の Moore-Penrose の一般逆行列であ る。この場合, 次式は成立するが, $A^{+} A=I_{n}\left(I_{n}: n\right.$ 次 単位マトリクス) は一般的には成立しない。

$$
\boldsymbol{A A}^{+}=\mathbb{I}_{m}
$$

以上より, 変位モード指定の形態解析問題は, 式 (2) を制約条件とする式 (1) の解析問題 (未知量は $x_{f}$ と $\boldsymbol{d}$ の一部）に帰着できた。しかし，このままの形式では 解析が困難であるので， $x_{f}$ のみを末知量とする基礎方 程式に定式化する。

式( 1 )は次式で与えられる全ポテンシャルエネルギー 関数 П の停留条件より得られる。

$$
\Pi=\frac{1}{2} \boldsymbol{d}^{\tau} \boldsymbol{K d}-\boldsymbol{f}^{\tau} \boldsymbol{d}
$$

そこで, 式（2）を制約条件とする上式の停留問題の定 式化に Lagrange 乗数法を適用する。Lagrange 乗数べ クトル $\lambda$ を導入し， $\boldsymbol{d}$ と $\lambda$ を知量とする制約条件無 しの停留問題に変換する。その場合の全ポテンシャルエ ネルギー関数として次式を採用する。

$$
\Pi_{k}=\frac{1}{2} d^{T} \boldsymbol{K d}-\boldsymbol{f}^{T} d+\lambda^{T} \boldsymbol{A d}
$$

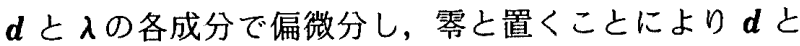
$\lambda$ を末知量とする次の連立方程式が得られる。

$$
\begin{aligned}
& K d-f+A^{T} \lambda=0 \\
& A d=0 \cdots \ldots \ldots \ldots
\end{aligned}
$$

ここで,

$$
\boldsymbol{r}=\boldsymbol{A}^{\mathrm{T}} \boldsymbol{\lambda}
$$

と置くと, 式 $(8)$ は

$$
\boldsymbol{K d}+\boldsymbol{r}=\boldsymbol{f}
$$

以上より，式（9）（11）が基礎方程式となる。ここ

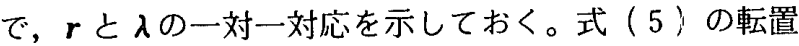
をとると $\left(\boldsymbol{A}^{+}\right)^{T} \boldsymbol{A}^{T}=\boldsymbol{I}_{m}$ となる。式 $(10)$ の両迅に $\left(\boldsymbol{A}^{+}\right)^{T}$ を掛けると

$$
\lambda=\left(A^{+}\right)^{T} \boldsymbol{r}
$$

$\boldsymbol{A}^{+}$は唯一に定まるから，rが与えられると入も唯一に 定まることがわかる。

\section{3. 変位モード指定の形態解析の定式化}

式 (11) において，Kは $x_{f}$ の関数であり， $x_{f}$ が変 化すると $\boldsymbol{r}$ も変化する。つまり，r无，の関数となる。 そこで，式（11）を次式のように書き換える。

$$
r\left(x_{f}\right)=f-K\left(x_{f}\right) d
$$

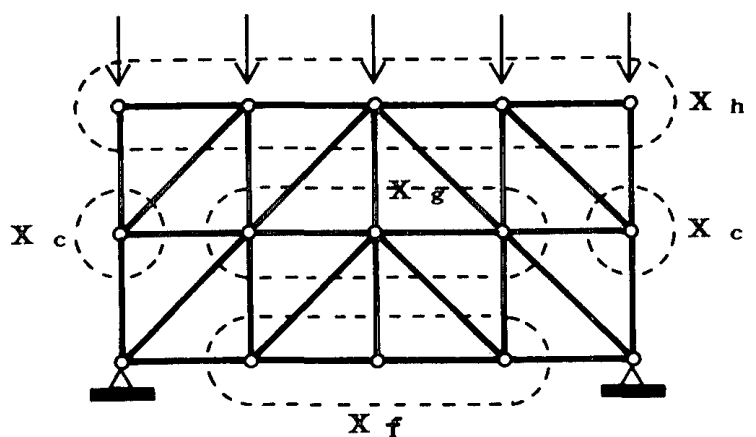

(a) 初期形態

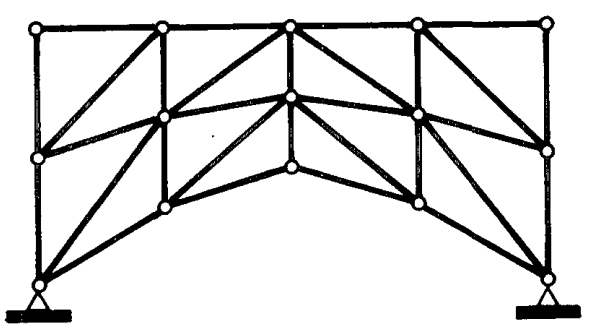

(b) 解形態

図一2 座標パラメータの分類 
解となる形態を $\bar{x}_{f}$ で表すと, 式（1)，（2）において, $\boldsymbol{K}\left(\bar{x}_{f}\right) d=\boldsymbol{f}, \boldsymbol{A d}=\mathbf{0}$ の両式を満足することから，

$$
\boldsymbol{r}\left(\bar{x}_{f}\right) \doteq \mathbf{0}
$$

以上より, 変位モード指定の形態解析は以下のように 定式化される。「 $x_{f}$ 形態を表す未知べクトルとする。 このとき,

$$
\begin{aligned}
& K\left(x_{f}\right) d+r\left(x_{f}\right)=f \\
& A d=0
\end{aligned}
$$

において, $\boldsymbol{r}\left(\bar{x}_{s}\right)=0$ となる $\bar{x}_{f}$ を求めよ。」

\section{Bott・Duffin 逆行列による $r\left(x_{s}\right)$ の定式化}

式（15)，(16）は $x_{f}$ を固定したとき，rとdの $2 n$ 個を末知量とする $(n+m)$ 個の連次一方程式となって いる。そこで, $\boldsymbol{r}$ ど $\boldsymbol{d}$ を分離し, $\boldsymbol{r}$ と $\boldsymbol{d}$ を $x_{\boldsymbol{s}}$ の関数と する方程式を作成する。そのため，ここではBott・ Duffin 逆行列を利用した解析法 ${ }^{16)}$ を採用する。

最初に $\boldsymbol{d}$ と $\boldsymbol{r}$ の直交性を示す。式:(10), (16) より

$$
d^{T} r=d^{T} A^{T} \lambda=(\dot{A} d)^{T} \lambda=0
$$

上式の関係より, $\boldsymbol{L}$ を $n$ 次元空間の部分空間, $\boldsymbol{L}^{\perp}$ を $n$ 次元空間の $L$ に対する直交補空間とすると

$d \in L, \quad r \in L^{\perp}$

となる。そこで, $\boldsymbol{P}_{L}: n$ 次元空間から $L$ 上への正射影 マトリクス, $P_{L^{\perp}}: n$ 次元空間から $L^{\perp}$ 上への正射影マ トリクス, $\boldsymbol{a}: n$ 次元内のベクトル，とすると次式が成 立する。

$$
\begin{aligned}
\boldsymbol{d} & =\boldsymbol{P}_{L} \boldsymbol{a} \\
\boldsymbol{r} & =\boldsymbol{P}_{L^{\perp}} \boldsymbol{a}
\end{aligned}
$$

式 (19),（20)，を式（15）に代人すると

$$
\left[K P_{L}+P_{L^{1}}\right] a=f
$$

上式より

$$
a=\left[K P_{L}+P_{L^{+}}\right]^{-1} f
$$

上式を式（19），(20）に代入すると

$$
\begin{aligned}
& \boldsymbol{d}=\boldsymbol{P}_{L}\left[\boldsymbol{K} \boldsymbol{P}_{L}+\boldsymbol{P}_{L^{1}}\right]^{-1} \boldsymbol{f} \\
& \boldsymbol{r}=\boldsymbol{P}_{L^{1}}\left[\boldsymbol{K} \boldsymbol{P}_{L}+\boldsymbol{P}_{L^{1}}\right]^{-1} \boldsymbol{f}
\end{aligned}
$$

式 (23) の係数マトリクスを $\boldsymbol{K}_{(L)}^{(-1)}$ と置くと $\boldsymbol{K}_{(L)}^{(-1)}$ は $\boldsymbol{K}$ の Bott・Duffin 逆行列と㭔ばれる。 $\boldsymbol{P}_{L}, \boldsymbol{P}_{L^{\perp}}$ は $\boldsymbol{A}$ によっ て定まったマトリクスとなり，Aが与えられると自動 的に作成することができる ${ }^{10)}$ 。

式（24）を式（14）に適用すると，解は次式を満足す る $x_{f}$ となる。

$$
\boldsymbol{r}\left(x_{f}\right)=\boldsymbol{P}_{L^{1}}\left[K\left(x_{f}\right) P_{L}+P_{L^{1}}\right]^{-1} f=0
$$

ここで，上式の位置付けを行っておく。式 (15)，(16) の定式化は， $A d=0$ を霂足させながら $K\left(x_{f}\right) d=f$ の誤 差 $\boldsymbol{r}\left(x_{f}\right)$ をとすることにある。他の定式化として， $\boldsymbol{K}\left(x_{f}\right) \boldsymbol{d}=\boldsymbol{f}$ を満足させながら, $\boldsymbol{A d}=\mathbf{0}$ の誤差 $\boldsymbol{e}\left(\boldsymbol{x}_{f}\right)$ を 0 とする方法がある。その場合の $e\left(x_{f}\right)$ は,

$$
\boldsymbol{e}\left(\boldsymbol{x}_{f}\right)=\boldsymbol{A} \boldsymbol{K}^{-1}\left(\boldsymbol{x}_{f}\right) \boldsymbol{f}
$$

で与えられる。本論文の目的は, Bott・Duffin 逆行列
を利用して式（25）の定式化を試みたものである。

\section{5. 数值解析法}

式（25）は $\boldsymbol{x}_{｝ \text { に関する非線形方程式であり，陽な形 }$ で解を求めることはできない。そのため，ここでは Newton-Raphson 法と最大傾斜法を用いで数值解析を行 う。

$$
\boldsymbol{f}\left(x_{f}\right)=\left|\boldsymbol{r}\left(x_{f}\right)\right|
$$

と置き, $f\left(x_{f}\right)=0$ となる $x_{s}$ 求める。以下では, $x=x_{s}$ として定式化を行う。. Newton-Raphson 法と最大傾斜法 は，反復法と呼ばれる手法である。まず，初期点 $x_{0}$ を 定め，次に解に接近する一連の点， $x^{(r)}(r=1,2,3$, $\cdots, n)$, つまり, $\boldsymbol{f}\left(\boldsymbol{x}^{(\dot{r+1})}\right)<\boldsymbol{f}\left(\boldsymbol{x}^{(\eta)}\right)$ の関係を満足する $x^{(r+1)}$ を求めて最小化を進める。

\subsection{Newton-Raphson 法}

点 $x^{(n)}$ における目的関数 $f(x)$ を, $x$ の接線勾配で近 似し最小化を進める。

$$
x_{i}^{(r+1)}=x_{i}^{(r)}-\frac{1}{\left(\partial f / \partial x_{i}^{(r)}\right)} f\left(x_{i}^{(r)}\right)
$$

ここに, $x_{i}^{(n)}: r$ ステップにおける $x$ の $i$ 成分, $x_{i}^{(r+1)}$ $:(r+1)$ ステップにおける $\boldsymbol{x}$ の $i$ 成分, $\partial \boldsymbol{f} / \partial \boldsymbol{x}_{i}^{(\eta)}: r$ ステップにおける $x$ の $i$ 成分による関数 $f$ の偏導関 数,である。

\section{2 最大傾斜法}

目的関数 $\boldsymbol{f}(\boldsymbol{x})$ の減少率が最大となる方向 $\boldsymbol{d}^{(r)}$ を求め, 最小化を進める。

$$
x^{(r+1)}=x^{(r)}+h^{(n)} d^{(r)}
$$

$$
d^{(\eta)}=\frac{1}{\left[\Sigma\left(\partial f / \partial x_{\imath}^{(\eta)}\right)^{2}\right]^{1 / 2}}\left[\begin{array}{c}
\partial f / \partial x_{1} \\
\partial f / \partial x_{2} \\
\vdots \\
\partial f / \partial x_{n}
\end{array}\right]
$$

ここに, $x^{(n)}: r$ ステップにおける $x, x^{(r+1)}:(r+1)$ ステップにおける $x, h^{(n)}$ : ステップ長さ, $d^{(n)}$ : 最大傾 斜方向ベクトル，である。ただし，ステップ長さ $h に$ ついては，解析傍における収束性を向上させるために次 の規則を適用する。

$$
\begin{aligned}
& \boldsymbol{f}\left(\boldsymbol{x}^{(r+1)}\right) \geqq \boldsymbol{f}\left(\boldsymbol{x}^{(r)}\right) \text { のとき, } h^{(r)}=h^{(n)} / 2 \\
& \boldsymbol{f}\left(\boldsymbol{x}^{(r+1)}\right)<\boldsymbol{f}\left(\boldsymbol{x}^{(r)}\right) \text { のとき, } h^{(r)}=h^{(n)}
\end{aligned}
$$

\section{6. 数值解析例}

本論文で提案した方法の有効性を確かめるため, 図一 3(a)に示す解析モデル (平面トラス) の数值解析を行う。 上弦節点に同一の鉛直方向荷重を作用させる。このとき の変位を図一 $3(\mathrm{~b})$ に示す。荷重が作用したよきの節点 $i$ の $X, Y$ 方向の変位を $D X(i), D Y(i)$ とすると, 上 弦節点 1，2，3 の鉛直方向（ $Y$ 方向）変位は $D Y(1)$, $D Y(2), D Y(3)$ となる。変位モ一ド指定として, 節点 1 , $2 ， 3$ が変形後においても同一直線上に並ぶ $(D Y(1)=$ 
$D Y(2)=D Y(3))$ ことを条件として設定する。このとき， 指定した変位モードを満足する構造形態, つまり, 節点 4, 5, 6の $Y$ 座標值を求める。ただし， $Y(4)=Y(6)$ とするので未知パラメー夕数は $2(Y(4), Y(5))$ となる。
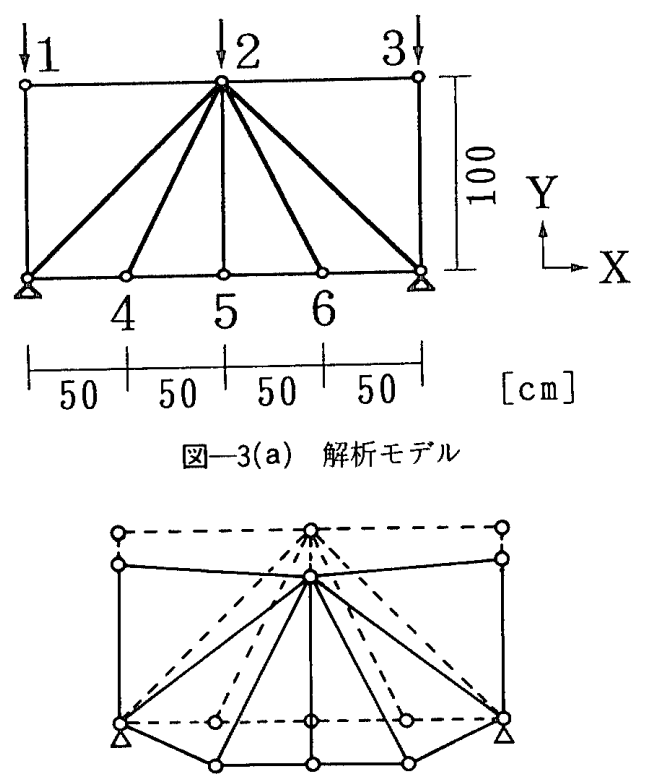

図一3(b) 変位図

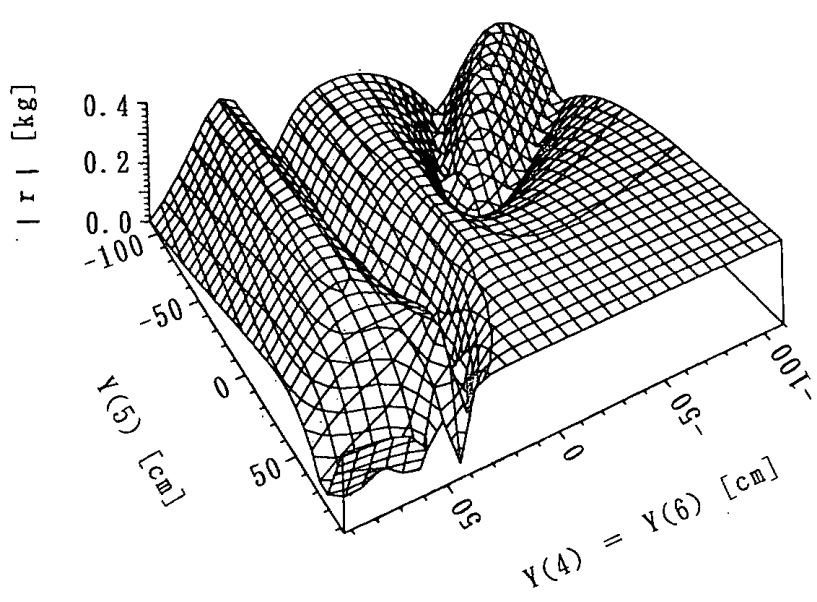

図一4 $|r|$ 曲面

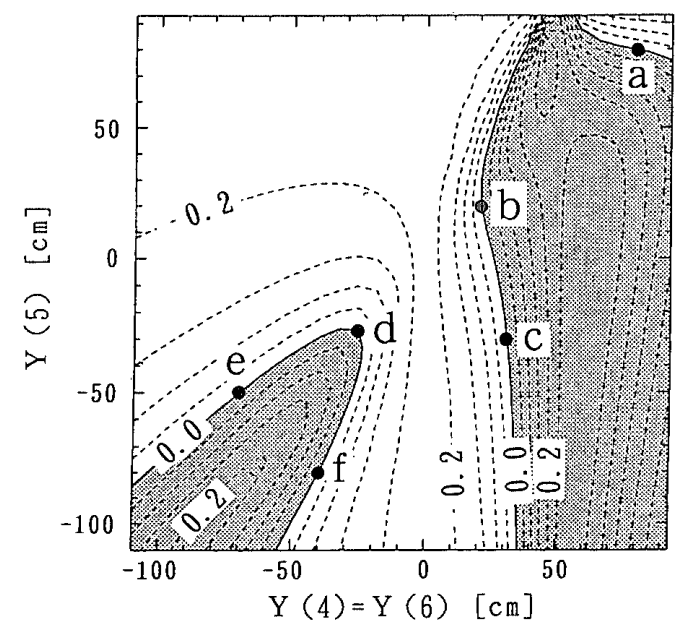

図一 $|r|$ 曲面の等高線図

この解析モデルにおいて, 式 (25) の $|\boldsymbol{r}|$ と $Y(4)$, $Y(5)$ の関係を図一4に示す。このように非常に複雑な 曲面となる。また， $|\boldsymbol{r}|$ 曲面の等高線図を図一5に示す。 $|\boldsymbol{r}|=0$ となる曲線（網かけ部の境界線）上の点が, 解 形態を与える。解形態の一例として, 図一 5 における点 (a) （f) の構造形態を図一6に示す。このように非常 に複雑な $|\boldsymbol{r}|$ 曲面において, 零となる点を効率よく求 める必要がある。そこで, $|\boldsymbol{r}|$ 曲面上での $|\boldsymbol{r}|$ の最小 化に, Newton-Raphson 法および最大傾斜法を適用する。 Newton-Raphson 法による $|\boldsymbol{r}|$ とステップ数の関数を, 図一7に示す。最大傾斜法による $|\boldsymbol{r}|$ とステップ数の関 係を，ステップ長さ $h=-1.0,-0.5,-0.25$ の場合 について, それぞれ図一8, 図一9, 図一10に示す。また, $Y(4)$ とステップ数の関係, $Y(5)$ とステップ数の関係 を図一11，図一12に示す。Newton-Raphson 法と最大 傾斜法を比較するために，平面的な収束状況を図一13 に示す。さらに，最大傾斜法の収束状況の詳細装図一14 に示す。この例の場合, Newton-Raphson 法では解が発 散している（解が得られた具体例は, 文献 18）に示し てある)。

このように, Newton-Raphson 法を採用すると，解を

(a)

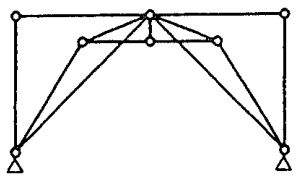

(c)

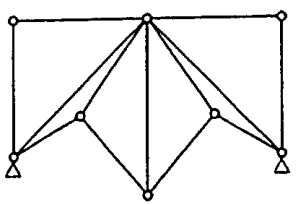

(e)

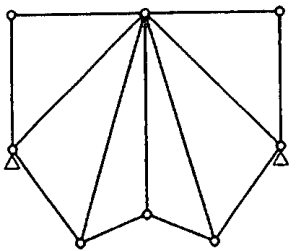

(b)

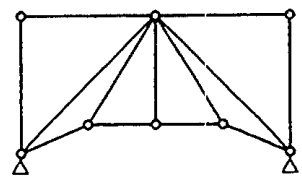

(d)

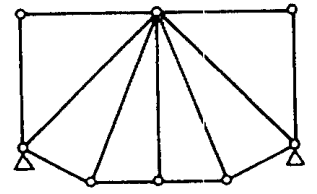

(f)

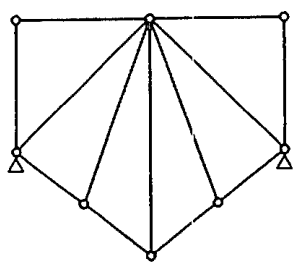

図一6 解形態

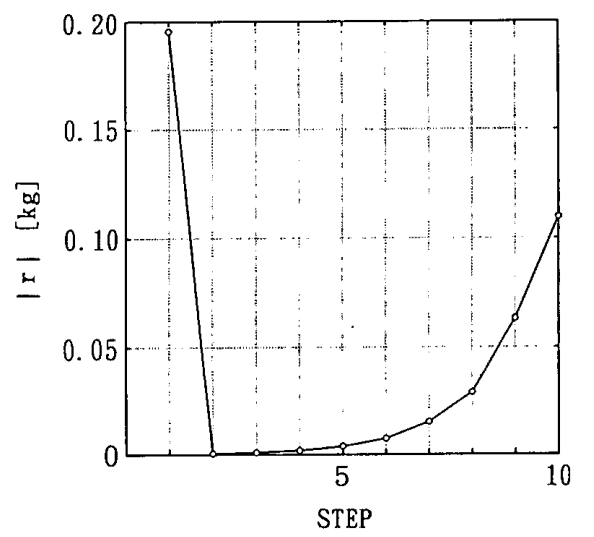

図一7 ステップ数と $|r|$ の関係 (Newton-Raphson 法) 
求めることが不可能である場合も存在することがわか る。最大傾斜法を採用した場合は必ず収束し，かつ，ス テップ長さ $h$ が小さいほど初期点に近い解に収束する ことがわかる。

\section{7. 結 語}

構造形態は（a）地震や風などの外部環境に対する抵 抗能力を確保すること, (b) 機能上の要求を満足する こと, (c) 人工構造物として環境に同化させること（美 しいこと等),など,種々の条件によって決定されてくる。 ここでは，(b) 項に属する問題として，与えられた外 力の作用下において, 変位モードを満足する構造形態解

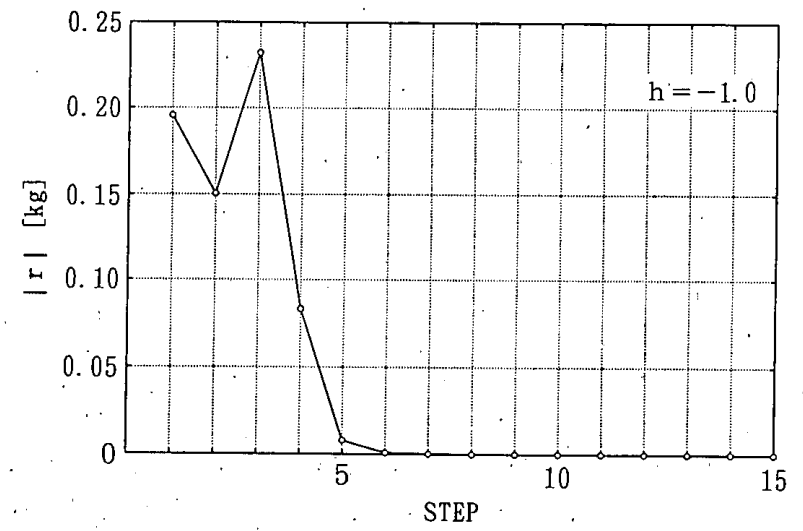

图一8 ステップ数と $|\boldsymbol{r}|$ の関係（最大傾斜法, $h=-1.0$ )

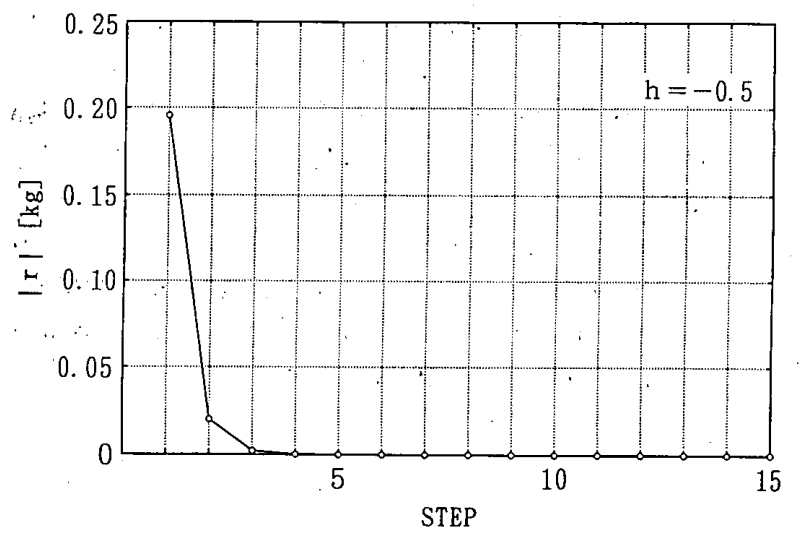

図一9 ステッブ数と $|\boldsymbol{r}|$ の関係（最大傾斜法， $h=-0.5$ )

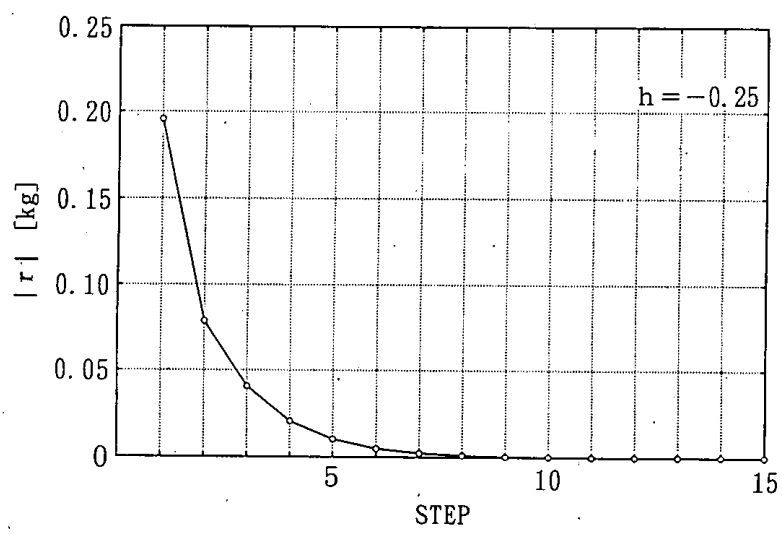

図一10 ステップ数と $|\boldsymbol{r}|$ の関係（最大傾斜法, $h=-0: 25)$
析法を述べた。

形態解析法は構造解析における逆問題のひとつとし て，高度な非線形問題に属している。そのため，解の存 在条件や唯一性条件をはじめ, 解析法自身においても未 解決の課題は多い。本論文では, 変位モードを満足する 構造解析法のひとつの定式化を提案し，具体例に適用し た。図一 5 に示すように，このような簡単な例でも無数 の解が存在する。そのため, 奏際の設計において無数の 解の中から，他の条件によって設計すべき形態を決定す ることが必要となる。

式 (25) で与えられる非線形方程式は，非常に複雑な $|\boldsymbol{r}|$ 曲面を形成している。そのため, 微分係数に直接依 存する Newton-Raphson 法では，解が得られない場合 が生じることがある（図一13）。今後，非常に複雑な $|\boldsymbol{r}|$ 曲面において，零となる点を効率よく求める数値解 析法が要望される。

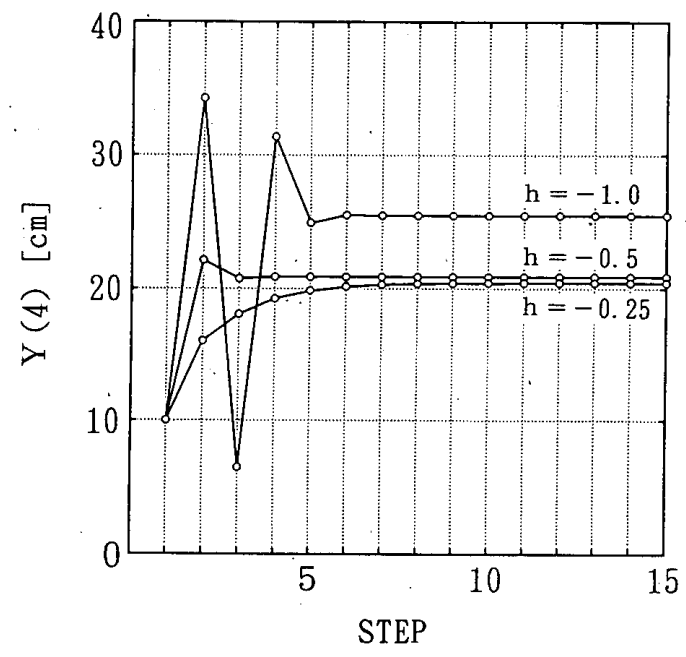

图一11 ステップ数と $Y(4)$ の関係（最大傾斜法）

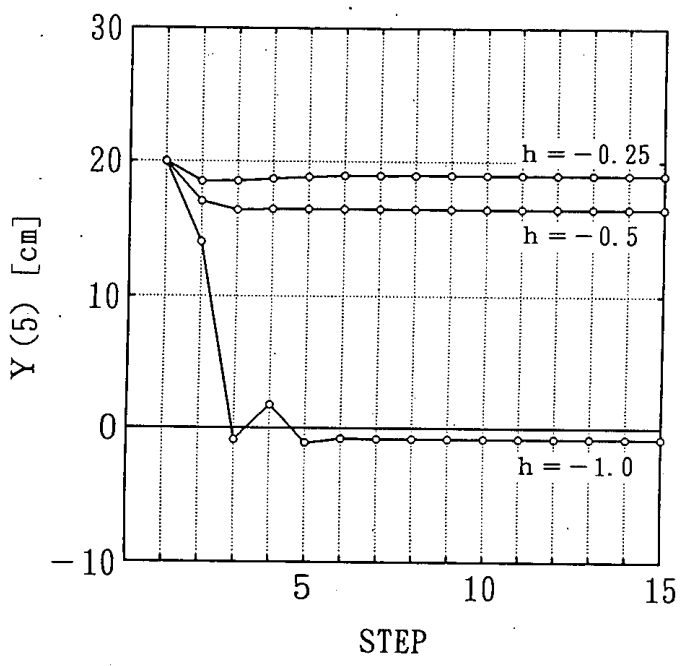

図一12 ステップ数よ $Y(5)$ の関係（最大傾斜法） 


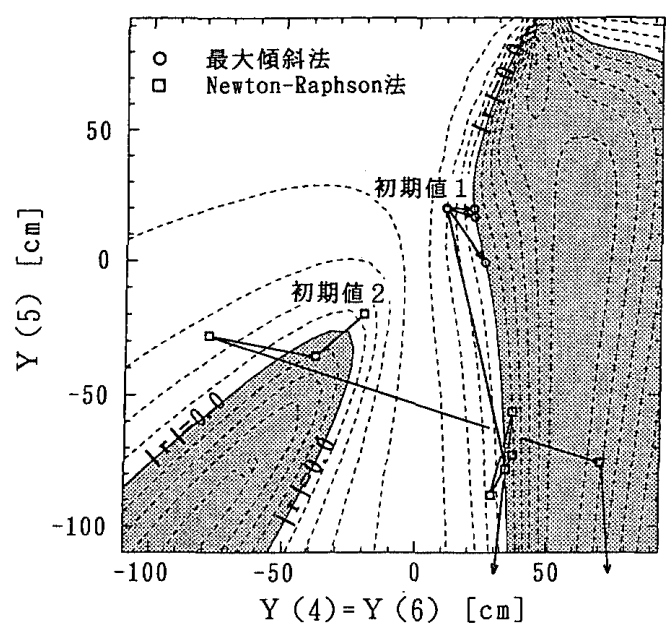

図一13 収束状況（Newton-Raphson 法と最大傾斜法）

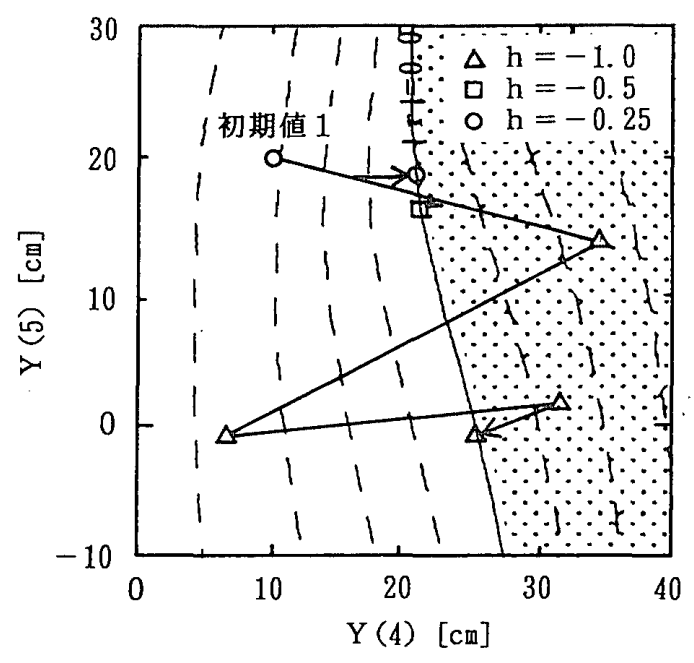

図一14 収束状況の詳細（最大傾斜法）

\section{参考文献}

1) 梅谷陽二：骨の形態と成長変形法, 日本機械学会誌, 第 79 巻 693 号, pp. $749 \sim 754,1976$.

2）尾田十八：機械構造設計の最適化手法とその応用 機械 の研究, 第 40 巻, 6 号, 1988.

3）中桐 滋：離散化モデルと棈造シンセシス 培風館, 1992.
4）瀬口靖幸，多田幸生：逆変分原理による構造物の形状決 定問題 日本機械学会論文集, 第 44 巻 381 号, pp. 1469 $\sim 1477,1978$.

5）畔上秀幸：成長の構成則を用いた形状最適化手法の提案 日本機械学会論文集, 第 54 巻 508 号, pp. $2167 \sim 2175$, 1988.

6) 半谷裕彦, 関 富玲：ホモロガス変形を制約条件とする 立体卜ラス構造の形態解析 日本建築学会構造系諭文報 告集, 第 405 号, pp. 97 102, 1989.

7) 中村恒善, 大崎 純：曲率半径をサブパラメータとした 振動数領域に対する最適円筒状立体卜ラス生成法 構造 工学論文集, 35 B, pp. 103 110, 1989.

8）中村恒善：トラスの形態創成と最適トポロジー自然生成 法 建築雑誌, Vol. 107, No. 1334, pp. 58 59, 1992.

9) 日本機械学会編：構造・材料の最適設計 技報堂出版, 1989.

10）半谷裕彦，川口健一：形態解析一一般逆行列とその応用 培風館, 1991 .

11）日本機械学会編：逆問題のコンピュータアナリシス コ ロナ社, 1991.

12）久保司郎：逆問題 培風館, 1992.

13）高木隆司：形の数理 朝倉書店, 1992

14) Topping, B.H.V. : Shape Optimization of Skeletal Structures, A Review, Journal of Structural Engineering, Vol. 109, No. 8, pp. 1933 1951, 1983.

15) Ding, Y. : Shape Optimization of Structures, A Literature Survay, Computers and Structures, Vol. 2:4, No.6, pp. 985 1004, 1986.

16）半谷裕彦, 関 富玲：Bott・Duffin 逆行列による変位制 限を持つ構造物の解析 日本建築学会構造系論文報告集, 第 396 号, pp. 82 86, 1989.

17）大森博司：変分原理を用いた構造形態力学に関する基礎 的研究 シェルと空間構造に関する夏期セミナー資料, 1991.

18) Y. Hangai, K. Harada, : Analytical Method of Structu ral Shape under the Prescribed Displacement Mode, Proceedings of the IASS-MSU International Symposium, pp. 499 506, 1993.

（1993 年 2 月 9 日原稿受理, 1993 年 8 月 17 日採用決定） 